\title{
The Pattani Malay Identity in Pantai Ini Lautnya Dalam Identiti Melayu Pattani dalam Pantai Ini Lautnya Dalam
}

\author{
SARAVANAN P. VEERAMUTHU \\ Pusat Pengajian Ilmu Kemanusiaan, Universiti Sains Malaysia, 11800 Minden, Pulau Pinang. \\ saravanan@usm.my
}

\begin{abstract}
This study is an examination of the portrayal of the Pattani Malay identity in the Pantai Ini Lautnya Dalam anthology by Abdul Razak Panaemalae. Ten short stories by the writer are analysed with specific focus on how this identity is presented or reflected through the characters based on the model of identity advocated by Phinney (1989). Four dimensions of identity - religion, language, economy, and politics - are highlighted in the discussion. Abdul Razak's stories present the perspective of the Pattani Malay community manifested through the 'world view' of youths entrenched in the dominant Thai culture. Analysis of the stories indicated that the Malay identity is still prevalent in the community. The cultural markers of language identity and religion identity are also ascertained. This indicated that the writer subscribed to the tenet of 'gentem lingua facit' or 'language reflects nation'.
\end{abstract}

Keywords: Identity, Pattani, Pantai Ini Lautnya Dalam, Abdul Razak Panaemalae, short stories.

Abstrak Kajian ini berkisar kepada pemaparan identiti Melayu Pattani dalam kumpulan cerpen Pantai Ini Lautnya Dalam. Unit analisis kajian ini terdiri daripada sepuluh buah cerpen nukilan Abdul Razak Panaemalae dalam Pantai Ini Lautnya Dalam. Aspek kajian bertumpu kepada citra identiti Melayu Pattani yang digambarkan melalui watak-watak yang menggerakkan cerita dalam rangkaian cerpen tersebut. Penelitian ini disandarkan kepada teori kajian identiti yang disarankan dalam model identiti Phinney (1989). Perbincangan dibahagikan kepada beberapa dimensi identiti iaitu agama, bahasa, budaya, ekonomi dan politik. Tuntasnya, nukilan Abdul Razak memperlihatkan identiti masyarakat Melayu Pattani dari sudut 'world view' generasi muda yang kini berada dalam lingkungan budaya Thai yang dominan. Analisis cerpen-cerpen ini menunjukkan bahawa identiti Melayu 
masih jelas. Selain itu, dua petanda budaya (cultural marker) dikesan iaitu identiti bahasa dan identiti agama. Hal ini membuktikan bahawa penulis berpegang kepada "gentem lingua facit", istilah Latin yang bermaksud "bahasa menunjukkan bangsa."

Kata kunci: Identiti, Pattani, Pantai Ini Lautnya Dalam, Abdul Razak Panaemalee, cerpen.

\section{INTRODUCTION}

The Pattani Malay community in Thailand are concentrated in three out of the fifteen provinces in the southern region of the country, namely Pattani, Narathiwat and Yala. This minority community subscribes to an identity and a culture different from the majority Thai group which holds political power. The dissimilarity in cultural practices and lack of political representation have consequently given rise to perceptions of suppression and a continued need to justify their existence or survival in their country. The literature of any society is a direct reflection of the social reality that occurs in the daily lives of the people; Umar Junus (1986) argues that writers create their art based on their social background and social document, with literary works often providing the backdrop that highlights the changes and evolutions that occur and impact the community as a whole.

This study is an examination of the concept of identity among the Pattani Malay as evidenced in ten selected short stories by Abdul Razak Panaemalae (2014) in Pantai Ini Lautnya Dalam. The characters in the stories provide the basis for the analysis of the aspects of perceived identity and the resultant effects on the Pattani Malay. 


\section{Concept of Identity}

The development of identity pertains to two types: first, the one that develops at the individual level, and secondly, the type that evolves in a cluster of people which would then have the potential to unite (Kim, 1994). Identity development is tied to many variables; Siti Munirah Kasim and Malo Rajo Sathian (2012) posit that the element of culture, language, religion, environment and attitude are among the key factors that determine identity formation or development at a deeper level. However, since research on identity is a dynamic process that changes according to time and context, it should be considered according to its development and variation (Phinney, 2003). The value of any investigation on aspects of identity is in its ability to provide information on:

“... [the] sense of belonging and as a symbol of survival of a certain community. In an identity, there are some elements which highlight the unique features that differentiate a group of people from another. All those elements consist of religion, language, dress, food, values, norms and many more. Hence, there are certain clusters of people (minority) which rise to oppose the policy of identity integration brought by the community in majority ..."

(Hasni Zakaria \& Novel Lyndon, 2014: 149)

Phinney's (1989) Identity Model, a model that focuses on the development of identity in a particular race, describes the event as a process that undergoes three stages. The first stage is characterised by a lack of exploration on ethnic characteristics; individuals at this stage are perceived as passive in responding to ethnic images and stereotypes, and likely to accept the cultures and values of the majority community which might include the internalisation of negative views or perceptions towards them as a minority.

Ethnic identity search emerges in the second stage with individuals beginning to evaluate and explore the purpose of their membership in their respective groups. The individual begins to form concepts of his own ethnic identity and comes to terms with the differences between his heritage culture and the dominant culture in his environment. He develops an awareness of 
the need to understand the culture of origin as part of the process that helps clarify personal perspectives on the meaning of his ethnicity.

The third stage, ethnic identity achievement, is considered the ideal stage in the process of identity formation. This stage is characterised by evident ethnic self-confidence with the individual acquiring a deeper understanding and appreciation of his identity through a process of selfreflection. This stage is closely related to acceptance and internalisation of own ethnic characteristics which would subsequently lead the individual towards making a commitment and integrating further into his community.

Phinney (1989) stresses that at this ethnic identity achievement stage, the individual would begin to demonstrate sense of ownership, confidence and pride in his ethnic heritage which can serve as a form of 'bleach' for the effects arising from prejudice and discrimination against ethnic issues in a pluralistic culture. In this last stage of ethnic identity construction, individuals are inclined towards finding viable and peaceful solutions to the problem of cultural differences between their group and the dominant group, and the gap or disparity in status and position in society (Phinney et al., 1990). As theorised by Phinney (1990), the meaning of ethnic identity achievement would differ for each individual or group as they might vary in terms of history and personal experiences. The process of ethnic identity formation therefore might or does not end with the attainment of ethnic identity but could continue in a cycle that involves further exploration or the process of re-evaluation of the role or meaning of a person's ethnicity (Parham, 1989). Assessment is made at this stage to explore the level of involvement of individuals in the activities closely related to their ethnicity.

\section{LITERATURE REVIEW}

In "Darah dan Air Mata Perjuangan Wanita di Tanah Selatan: Menerusi Novel 'Lukanya Merah' Karya Rohani Deraman", Siti Hajar Che Man (2015) portrays the tenacious or never-say-die spirit of an old woman in the character of Mek Romah who later becomes a source of inspiration amongst Pattani Malay youths. Rozais al-Anamy (2014) argues that the underlying theme in this novel is based on women's fight or struggle from 
two perspectives: first, the perspective of people shielded from the outside world, and secondly, the perspective of Muslim Malay women's fight which however is not in conflict or enmity with men.

The struggle of the Pattani Malay in the mass media is also discussed by Rahimah A. Hamid, Md. Salleh Yaapar and Syahidatul Munirah Badrul Munir (2015) in "Lirik Lagu Perjuangan Melayu-Islam Pattani Media Baharu: Suatu Analisis". In this research, the lyrics of a song for fight or quest shared via the internet is examined using Max Weber's theory of authority or power which encompasses the aspects of finance and harshness such as the usage of weapons and charisma. Sohaimi Abdul Aziz (2015) in "Konflik Melayu Pattani dengan Pihak Berkuasa Thailand: Kajian Strategi Retorik dalam Laman Sesawang" scrutinises the benefits of the media as a tool for voicing the opinions of the Pattani Malay community pertaining to the emerging conflicts and strategies used to influence the masses. This research is based on textual analysis that uses discursive and rhetorical analyses along with culture.

The Southern Thai conflict is also discussed in Mohamad Luthfi Abdul Rahman's (2015) “Kemelut Di Pattani dalam Karya Tradisional dan Moden: Satu Kesinambungan dalam Hikayat Pattani dan Pantai Ini Lautnya Dalam" in which the crisis in Pattani is scrutinised in the context of both the traditional and modern periods. In the traditional context, problems and unrest in Pattani are portrayed in "Hikayat Pattani." For the modern context, the collection of short stories and poems in 'Pantai Ini Lautnya Dalam' by Abdul Razak Panaemalae is used for analysis.

In "Perwatakan Abdul Kadir dalam Dua Cerpen Thai: Suatu Perbandingan", Abdul Razak Panaemalae (2015) discusses "Maew Bukit Kreso" ("Bukit Kreso Cat" by Kanokpong Songsompant) and "Tawan Chon Saeng” "“The Sun Shines Its Rays" by Narongrit Sagdaronnarong). Both of these Thai short stories are similar in their thematic aspects which relate to the violent conflicts in the Muslim Malay community in Southern Thailand.

In Rahimah A. Hamid's (2015) article "Puisi-Puisi Exile Mahroso oh: Suara dari Tanah Asing dalam Kiblat Cinta-Kumpulan Sajak Suara 
Bunga Pattani", the word 'exile' is explained from the viewpoints of several scholars and its emergence in the poems of Mahroso Doloh is discussed in relation to two aspects: first, the reaction of the writer in 'exile', and second, the experiences of the writer in 'exile', with the conclusion that 'exile' refers to literary works of relief or calmness, either in the land of migration or in the native land.

Siti Hajar Che Man and Aminoh Jehwae (2013) present a textual analysis of Pattani Malay poems based on Abu Busairi Bujuri's (1989) poetry collection, "Di Gapura Takwa". From the historical and sociological perspectives, the fight of the Pattani Malay community is often heavily emphasised, for instance, as in "Strategi Perjuangan Melayu Islam Pattani Dahulu dan Kini: Suatu Sorotan" in Merekayasa Kearifan Tempatan: Budaya, Pelancongan, Arkeologi dan Sejarah (Mohd. Roslan Mohd Nor, Ahmad Zaki Berahim, Marobidi Kamae \& Hamidah Jalani, 2014). The struggle of the Pattani Malay is also discussed in Sejarah Perjuangan Melayu Pattani 1785 - 1954 (Nik Anuar Nik Mohamed, 2006) whereby their quest to free their beloved Pattani from Siamese rule and rejoin Tanah Melayu (Malaya) is focused on. This article also examines the reactions of Britain and Siam pertaining to this move by the Pattani Malay.

Rohan Gunaratna and Arabinda Acharya's (2013) "The Terrorist Threat from Thailand: Jihad or Quest for Justice" focuses on the attempts to link the rebellion or uprising in Pattani with global 'jihad' and the war against violence in the right perspective. The injustice by Thai authorities against the people of Southern Thailand which subsequently gives rise to prolonged or on-going conflicts is depicted here. Issues in Southern Thailand cannot be addressed lightly as they are different from the Cold War with the current conflict especially pertaining to the religious identity having inter-border implications. "Pattani Behind the Accidental Border: The Search for Elusive Peace" by Kijang Mas Perkasa (2010) presents an analysis on the upheavals in Southern Thailand with the overview that the past history of Pattani cannot be disregarded when discussing the current conflicts in the province. 
In "Politik Thai dan Masyarakat Islam Di Selatan Thailand", Ahmad Omar Chapakia (2000) explores the policies and political actions of the Thai government on the Islamic community in Pattani and their reactions to the issues at hand. The research is focused on five areas in the Southern Thai province, namely Pattani, Yala, Narathiwat, Satun and Songkhla, due mainly to these areas having their own self-identity with respect to their historical background, religion, race and culture. All five are perceived as sensitive areas in the context of Thai politics.

\section{Identity in Pantai Ini Lautnya Dalam}

Ten short stories from Pantai Ini Lautnya Dalam - "Ana Bukan Ustaz", "Kehilangan", "Surat Terbuka Kepada Cikgu Anuban", "Ceritera Kambingkambing", "Cinta Kuala Lumpur", "Seorang Guru, Sebidang Tanah, Sebuah Kereta dan Hati Seorang Ayah", "Kerajaan Takut", "Senyuman S", "Hayi Somkiat" and "Negara Ten-Pol" - are explored in this study with the discussion centred on the emergent identities and the extent to which the characters reflect the level of identity found in the Phinney's Model.

The character, Somkiat in "Hayi Somkiat" reflects the characteristics specified by the Phinney's Model. Somkiat projects no desire towards any achievement of the identity of his race, reacts in a passive manner and even views his ethnicity negatively, and is accepting of the mainstream culture (Abdul Razak, 2014).

According to father, Somkiat's name is Wan Ishak. Dad always calls him Sohok. Can't particularly say when he changed the name to the Siamese name. Less certain, says the father. To be certain, since studying in Bangkok, Wan Ishak was replaced with the name Somkiat.

(Abdul Razak, 2014: 89)

The evolution from the Malay name 'Wan Ishak' to the Siamese 'Somkiat' occurs over the period of the young man's education in Bangkok. This conscious name change by the character supports Abdul Razak's contention of the education system is among the reasons that causes the Pattani Malay to be hindered in their search of their own identity. Those who 
are integrated into the Thai mainstream education system would eventually begin to embrace the change and forsake their heritage in several manners such as the shedding off of heritage-bound or heritage-indicative names.

A similar scenario is presented in "Kehilangan" which tells of Dr. Kamal who visits his Pattani Malay friend and is shocked by the change that he witnesses. His friend, Dr. Preecha whom he had admired as a person brave enough to question the future direction of the Malay Pattani has finally abandoned the Malay language in favour of spoken Thai in his daily interactions. Dr. Kamal quietly expresses his sadness and disappointment over this change:

Feeling shy, he only pretended to understand. He must accept the fact that this is Thailand and the appropriate language to be used is Thai and not Malay. This is a reality; not an imagination. Gradually, Dr. Kamal began to accept it. Previously, he might be influenced a lot by the concept of Malay in the Malay Festival. The era of the Malay world power in the region had passed. The Malay world had fallen apart according to the Western concept of nation.

(Abdul Razak, 2014: 26)

The writer's feelings on this issue, conveyed through the character of Dr. Kamal, reveals the extent in which the survival of Pattani Malays is hindered by reality and their status as a minority group which oftentimes has to concede to the dictates of the mainstream culture. The writer conveys his own sadness and regret at the eventuality that could very well befall the Pattani Malay society through his reflection "... he began to doubt the sacred words of Hang Tuah, 'Takkan Melayu hilang di dunia' (Abdul Razak, 2014: 26).

The issue of language loss or de-emphasisation is also highlighted in “Surat Terbuka Kepada Cikgu Anuban.” Abdul Razak's anxiety is clearly evident in this story whereby he uses the character 'Aku' to convey his stance. As a father, who worried about losing the dignity or prestige of the Malay language, 'Aku' argues: 
Teacher, it is not that I do not want to see my son speak fluently in the Thai language. I do not deny the importance of the Thai language. I do realise that the Thai language is essential to us in today's context. What's more, the Thai language is the official language of this country.

(Abdul Razak, 2014: 29)

This passage is reflective of the reality that is accepted by 'Aku' on the position or status of the Pattani Malay and the need to concur with the policies set by the Thai government. However, 'Aku' is unwilling to see the language of his heritage continues to deteriorate due to current developments. His stand is conveyed in his letter to his son's teacher who had advised him to continue using the Thai language in their daily interactions at home.

However, there is one thing that often disturbs my mind. I fear that if too much focus and emphasis is given to the Thai language, they might not be able to speak Malay in future.

(Abdul Razak, 2014: 30)

The above is perhaps driven by an awareness of the truth in the Malay phrase, 'Hilang bahasa hilanglah bangsa', which means that when a language is lost, the race would eventually follow a similar fate. The writer presses this through the lines:

Teacher, this is a very big crisis that has hit the Malays here. This is a significant phenomenon in our society today. The fact that we have to equally and considerably reflect. I do not mean that the teacher should use the Malay language when teaching the children in school. That is not what I am trying to say. I am simply explaining our position of these days so that at least we can handle the dilemma that surrounds our society today.

(Abdul Razak, 2014: $31-32$ )

The identity of the teacher in this story tells us how passive he is towards the issue of heritage language and demonstrates his determination to adhere to the requirements of the national education policy. He in fact goes further to give recommendations and advice to the parents to ensure the best possible 
outcomes for their children in the context of their existing environment. The child's mother is swayed by the teacher's 'warning'; however, 'Aku' outlines his expectations when at the end of the story he says:

I just want them to be aware of the identity of their own origins. I do not want them to experience a crisis in their identity in the future. I do not want them to face the same fate as the people of Turkey.

(Abdul Razak, 2014: 33)

Besides that, the influence or role of government policy in determining the customs and life of the Pattani Malay society is also discussed. The policies imposed by the Thai government have in fact made the Pattani Malays feel an even greater need or pressure to preserve their customs and traditions. It is evident in the short story "Senyuman $S$ ".

"What's wrong if we learn to eat by hand? Or, learn to eat using a spoon by ourselves? Is it wrong?"

I replied, "Not to say that it is wrong since it is not wrong actually but it would be better if we continue for eternal sake. Our culture has its own history, its own origin. We should not leave our culture just to follow others".

"What is lacking in our culture?" Mom looked earnestly.

(Abdul Razak, 2014: 79)

The mother character, a representative of the older generation, is utilised by Abdul Razak to convey his stand to the younger generation. Although the issue that is presented might seem trivial to the casual onlooker, the issue of how to eat touches on a core aspect of the Malay culture and is significant in how the older generation of the community conducts their everyday life. The man's mother urges him to adhere to their customary practice. In fact, this story is symbolic of the love of ' $S$ ' (could be a Siamese) and ' $M$ ' (could be a Malay) which pinpoints to the duality of nature in young people who are at crossroads. Finally, the young man begins to understand and accept that ' $\mathrm{M}$ ', his mother's choice, is more suitable and attractive for him. 
Government policies affect culture and life. According to Kamarulzaman Askandar (2006), culture and religion are important factors in life because they act as foundation and influence the way individuals or groups view and do certain things. There is a need for this culture to be respected and preserved from any form of influence or external elements. This is significant in "Ceritera Kambing-kambing" whereby the presence of the City Mayor who tries to 'clean' the city poses problems to the Malays. Tuk Imam's character represents the Pattani Malays who are oppressed by the government:

Tuk Imam agreed with the words of the City Mayor. But deep in his heart he also wanted the Mayor to understand even better the nature of the community there. They were used to living in such a situation. Before Pattani was upgraded to a city, Kampung Cabang Tiga was only a small village inhabited by the Malays.

(Abdul Razak, 2014: 44)

In the end, when the Malays in Pattani accept the changes proposed by the government, it becomes clear that the conditions in turn create new issues such as road accidents. The writer seems to be of the opinion that the changes based on the interpretation of the majority would lead to new problems for the Pattani Malay minority.

"Negara Ten-Pol" is about the Pattani Malay still in search of identity. The writer views the presence of the army and police especially in the southern regions of Thailand as a phenomenon that confuses the community:

We're just ordinary decent people who only deserve to be marginalised. Thus, we are bullied anytime and anywhere. We are just like a ball being kicked here and there to reach their respective targets. When the ball hits into goal, the cheering of supporters will be overwhelming.

(Abdul Razak, 2014: 103)

This passage demonstrates clearly the fate that befalls the Pattani Malay and Muslims in southern Thailand who could not understand what should be done to sustain the continuity or survival of their people. Anger is also evident through the following statement: 
Supposedly they are skilled enough to teach us to live in harmony and peace. Adopt a culture of tolerance. But their attitudes do not show such elements. When will we have a safe area if the authorities themselves are disputing among themselves? The most irritating would be when they did not want to understand our cultural background. Instead, they want to bribe us with their culture. It is not that we do not want to learn their culture. We have gone all out to advise our children and grandchildren to learn their language and culture. At least they should also know and understand our culture.

(Abdul Razak, 2014: 105)

It becomes apparent that the characters in the stories are still in the process of searching for their own identity. It needs to be acknowledged however that at this stage there is likely to be a sense of ownership, confidence and ethnic pride. The construction of ethnic identity propels the individuals of the minority ethnic to find peaceful solutions for the problem of cultural differences between them and the dominant group, and the low status positions contextualised in the broader context of society as portrayed in "Negara Ten-Pol”:

The Ten tribe was really dissatisfied when they found out that almost the entire people in that population could not master the official language. In fact, they are using their own language for the daily usage.

"Stupid!" yells the Ten tribe.

From our point of view, they are the ones who should be blamed instead of us because they did not want to understand our language and culture at all. Supposedly, they should have learnt a bit of our culture before coming on duty to our place.

Indeed, since the beginning we have been taught that our country is monoculture. There is no other culture other than the culture of the country. Whatever culture you were before, it is no more important because we are now under the auspices of another culture. We are asked to forget our culture and transform into new human being 
basedon the image of a culture or the culture of the country. However, should it be done and do we need to sacrifice our own origins?

(Abdul Razak, 2014: 105 - 106)

The writer concludes with a poser: the minority has accommodated new elements taken in from the host environment but the efforts seemed to be one-way only. Even worse, they are often blamed. This has forced the Pattani Malay to seriously consider whether they should abandon their cultural heritage that has been stable for many generations but is now unfortunately subjected to attacks and erosion due to government policies that favour only one culture i.e. the dominant culture.

Another clear identity portrayed in Abdul Razak's short stories is religious identity. The Pattani Malay is disadvantaged in that the religion of their profession - Islam - is oftentimes linked, however erroneously, to rebellion. This has resulted in them being subjected to various government actions and policies aimed at addressing such perceived threats. This issue is portrayed very clearly in "Hayi Somkiat" for instance whereby the Pattani Malay community eventually believes in the government propaganda and shows no sympathy or inclination towards religious issues. This attitude could be seen clearly in this passage:

And the more disappointing would be, in an interview on TV, he blasted the fighters.

"It is reasonable for them to be shot because they were not the martyrs.

They were only under the guise of religion for the sake of selfishness.

Islam does not teach us to be rude. Islam is a tolerant religion. A religion of peace," he said fluently in the Siamese language.

(Abdul Razak, 2014: 90)

Religious issues are highlighted in "Ana Bukan Ustaz" where Fauzi denies being an Ustaz (Islamic religious teacher) although many refer to him as one. Fauzi realises that this religious identity inherited by him is not only without any benefit but also created problems for him. He therefore refuses to be associated with the title: 
"I am not an Ustaz," Fauzi said that each time he was greeted as one. And so he denied whenever anyone referred to him as an Ustaz. From the very beginning, he was denying that he was an Ustaz. Somehow suddenly, he did not like anyone to call him so.

(Abdul Razak, 2014: 1)

This passage clearly shows that Abdul Razak is aware of the existence of Pattani Malay-Muslim groups that have been influenced by government propaganda. Religious identity in the Pattani Malay community is perceived as a uniting factor that could later pose as a threat to the government.

Religious issues are embedded clearly in "Kerajaan Takut" which tells the story of the fear, expressed through the character of Ibu that is prevalent in the Pattani Malay-Muslim community.

My mother is also like the other people who do not want to be involved in violence, either directly or indirectly. Silence is the safest way. Even silence could not solve any problems, but it might be the best option.

(Abdul Razak, 2014: 73)

Fear and anxiety are highlighted in this story when 'Aku' has to go to Malaysia to avoid becoming a victim of political violence. In addition, the non-economical value of religious identity is impressed on the young people in the community engaged in religion. In "Seorang Guru, Sebidang Tanah, Sebuah Kereta dan Hati Seorang Ayah", the plight of Nuawar, a teacher at a religious school, who could not afford to even buy his own daily needs is emphasised. This story also narrates the suffering experienced by the Pattani Malay who, in order to support or educate their children, have to pawn their valuables or borrow money from banks. Nuawar and his father are so desperate to meet their needs:

"Nuawar! If you insist on buying them, buy using your own money, Dad could no longer mortgage the land grant to the bank," said the father in quite a high voice. 
The economic identity of the Pattani Malay is also evident in "Cinta Kuala Lumpur" whereby the 'Aku' in this story says:

Life in this village never promises anything. Light at the end of the tunnel does not seem in even the slightest. The life table has not changed, practically the same, stereotype it is, says the people.

(Abdul Razak, 2014: 51)

Many of the teenagers in Pattani had to move out of their ancestral village, just like the character 'Aku' from Kampung Pohon Perah, 'Yingo' and 'Tipah' from Kampung Teluk Kapur in the district of Yamu. 'Aku' argues:

What is there in my village other than old rubber trees and a strip of dryland and a sad story? My village never promises a glorious future.

(Abdul Razak, 2014: 52)

In the story, the economic condition deteriorates over time and although the young people in the community live as per their traditional and cultural dictates, they are in actuality acutely seeking new beginnings. Whatever they have inherited mean little, or nothing at all. Here, Abdul Razak is in essence providing voice and form to the unspoken sentiments, fears and hopes of the younger generation in the Pattani Malay community.

The writer's stories reflect the dimensions of religion, language, culture, economy and politics among the Pattani Malay as they search to form foundations and establish their identity as a minority group. Che Mohd Aziz Yaacob (2012) describes this predicament:

The identity of a group involved in the conflict is dynamic... the group will be constantly changing in a multi-dimensional way as it is felt necessary to adapt to the dynamic conflict. This adjustment is necessary to generate a comfortable position in the conflict either when pressed or when going against. Minority groups in particular will feel comfortable to change together as they are able to produce strength and protection in dealing with the oppressing party. Furthermore the leader in the group promises that their needs will be taken care of provided that the orders are being followed as they are. 
In several of the ten selected short stories in Pantai Ini Lautnya Dalam, the characters are portrayed as being in the first stage of Phinney's (1989) Ethnic Identity Formation Model. In this stage - unexamined ethnic identity - four criteria are outlined: (1) lack of ethnic exploration, (2) passive response to ethnic images and stereotypes, (3) unrated positive or negative outlooks with regards to their group, and (4) acceptance of the cultural values and attitudes of the majority society. This includes those who internalise the negative views of the majority group towards people of their ethnicity. Some at this stage would perceive heritage as irrelevant with no bearing at all on their success in life. Being Pattani Malay therefore is viewed in a passive light with community members generally unopposed towards assimilating cultural values propounded or dictated by the dominant majority as reflected in characters like Hayi Somkiat ("Hayi Somkiat"), Aku ("Aku Bukan Ustaz"), Aku ("Cinta Kuala Lumpur"), and Nuawar ("Seorang Guru, Sebidang Tanah, Sebuah Kereta dan Hati Seorang Ayah”).

At the search or exploration stage, an individual begins a process of assessing and exploring which requires them to make peace with the dominant culture. Consequently, they will learn that understanding the culture of origin is part of the process that could help them make sense of their personal perspective or ethnicity. Several characters in Pantai Ini Lautnya Dalam are depicted in this manner: reflecting and evaluating their heritage, and finding ways to reconcile with the identity of the dominant Thai culture. The characters of Aku in "Kerajaan Takut", Aku in "Kehilangan", and Tuk Imam in "Ceritera Kambing-kambing" are inclined towards assimilation and accommodation between the original and dominant cultures due perhaps to their awareness of the reality of their status and position.

The stage of access of ethnic identity is when the process of identity formation occurs; here individuals would project confidence about their ethnicity and exhibit understanding of the meaning of their identity as a result of acceptance and internalisation of their ethnic characteristics. The characters in Pantai Ini Lautnya Dalam demonstrate this ethnic achievement level whereby they become proud of their heritage, for instance Aku in "Surat Terbuka Kepada Cikgu Anuban" where Sompang and his dad feel proud of their traditional values and Malay-Muslim identity. 


\section{CONCLUSION}

This study reviews the literature on Pattani Malay identity portrayed in ten short stories in Abdul Razak Panaemalae's Pantai Ini Lautnya Dalam. The stories reflect the identity of the community from the 'world view' perception of the younger generation who are entrenched in the dominant Thai culture. It is apparent that the identity of 'Malayanisation' is present in these stories. In addition, two cultural markers are clearly evident: identity of language and identity of religion which are indicative of Panaemalae's belief of "gentem lingua facita" or "language reflects the race". The issue of language use in both daily life and education is explored consistently through the diverse themes contextualised in the stories. The Islamic identity is also significant with religious institutions such as the mosque, 'surau', 'sekolah pondok' and religious council often providing the backdrop in many of the stories. Through these stories, the identity of the Pattani Malay in the context of the political realities in Southern Thailand is subtly and implicitly portrayed with cultural identity, a culmination or meeting point of several cross-cultural influences.

\section{REFERENCES}

Abdul Razak Panaemalae. (2014). Pantai Ini Lautnya Dalam. Kuala Lumpur: ITBM.

Abdul Razak Panaemalae. (2015). Perwatakan Abdul Kadir dalam Dua Cerpen Thai: Suatu Perbandingan. MELAYU: Jurnal Antarabangsa Dunia Melayu, Vol. 8 (2): hlm. $245-256$.

Ahmad Omar Chapakia. (2000). Politik Thai dan masyarakat Islam di selatan Thailand. Alor Setar, Kedah Darul Aman: Pustaka Darussalam.

Che Mohd Aziz Yaacob. (2012). Asimilasi bangsa Melayu di Pattani: Keberkesanan dasar dan survival budaya minoriti. Jebat: Malaysian Journal of History, Politics \& Strategies Studies, Vol. 39 (1): hlm. 97 - 123.

Hasni Zakaria \& Novel Lyndon. (2014). Identiti budaya dan bahasa etnik Melayu Thesaban Takbai,Selatan Thailand: Satu analisa fenomenologi. Geografia, Malaysian Journal of Society and Space, Vol. 10 (6): hlm. 148 - 155.

Kamarulzaman Askandar. (2006). Budaya perdamaian budaya kita. Pulau Pinang: Research and Education for Peace Unit \& Southeast Asian Conflict Studies Network. 
Kijang Mas Perkasa. (2010). Pattani behind the accidental border: The search for elusive peace. Kuala Lumpur: Orion Solutions.

Kim, Young Y. (1994). Beyond cultural identity. Intercultural Communications Studies, IV: 1.

Parham, T. A. (1989). Cycles of psychological nigrescence. The Caunseling Psychologist. 17: hlm. $187-226$.

Mohamad Luthfi Abdul Rahman. (2015). Kemelut di Pattani dalam Karya Tradisional dan Moden: Satu Kesinambungan Hikayat Pattani dan Antologi Cerpen Pantai Ini Lautnya Dalam. Rahimah A. Hamid \& Mohamed Nazreen (Peny.) Prosiding Diskusi Karya Pattani, Universiti Sains Malaysia.

Mohd Roslan Mohd Nor, Ahmad Zaki Berahim, Marobidi Kamae \& Hamidah Jalani. (2014). Strategi Perjuangan Melayu Islam Pattani Dahulu dan Kini: Suatu Sorotan. Nazarudin Zainun \& Darlina Md. Naim. Kearifan Tempatan: Merekayasa Kearifan Tempatan Budaya, Pelancongan Arkeologi dan Sejarah. Pulau Pinang: Penerbit USM.

Nik Anuar Nik Mahmud. (2006). Sejarah perjuangan Melayu Pattani. Bangi: Penerbit UKM.

Phinney, J. S. (1989). Stages of ethnic identity in minority group adolescents. Journal of Early Adolescence, 9: hlm. $34-49$.

Phinney, J. S. (1990). Ethnic identity in adolescents and adults: Review of research. Psychological Bulletin, 108: hlm. 499 - 514.

Phinney, J. S. \& Alipuria, L. (1990). Ethnic identity in college students from four ethnic groups. Journal of Adolescence, 13: hlm. 171 - 184.

Phinney, J. S. (2003). Ethnic identity and acculturation. Dlm. K. Chun, P. Organistaa \& G. Marin (Eds.), Acculturation: Advances in theory, measurement, and applied research, $(63$ - 81). American Psychological Association: Washingtion DC.

Rahimah A. Hamid. (2015). Puisi-puisi Exile Mahroso Doloh: Suara dari Tanah Asing Dlm. Rahimah A. Hamid \& Mohamed Nazreen (peny.). Kiblat CintaKumpulan Sajak Suara Bunga Pattani, Prosiding Diskusi Karya Pattani, Universiti Sains Malaysia.

Rahimah A. Hamid, Md. Salleh Yaapar \& Syahidatul Munirah Badrul Munir. (2015). Lirik lagu perjuangan Melayu-Islam Pattani media baharu: Suatu analisis. MELAYU: Jurnal Antarabangsa Dunia Melayu, Vol. 8 (2): hlm. 288 - 309. Rohan Gunaratna \& Arabinda Acharya. (2013). The terrorist threat from Southern Thailand: Jihad or quest for justice. Virginia, USA: Potomac Books Inc.

Rozais al-Anamy. (2014). Fiksi Sejarah Kekejaman di Pattani. Utusan Malaysia. Siti Hajar Che Man \& Aminoh Jehwae. (2013). Penerapan Teori Takmilah dalam Sajak-sajak Melayu Pattani. Dlm. Halimah Mohamed Ali \& Mohamad Luthfi Abdul Rahman (ed.), Sastera dalam Budaya dan Media. Pulau Pinang: Penerbit USM. 
Siti Hajar Che Man. (2015). Darah dan Air Mata Perjuangan Wanita di Tanah Selatan: Menerusi Novel Lukanya Merah Karya Rohani Deraman. Dlm. Rahimah A. Hamid \& Mohamed Nazreen (peny.). Prosiding Diskusi Karya Pattani. Universiti Sains Malaysia.

Siti Munirah Kasim \& Malo Rajo Sathian. (2012). Betunjangkan akar yang sama, pokoknya tidak semestinya serupa: Identiti kemelayuan Bangkok. Manusia dan Masyarakat, 23: 19 - 43.

Sohaimi Abdul Aziz. (2015). Konflik Melayu Pattani dengan pihak berkuasa Thailand: Kajian strategi retorik dalam laman sesawang MELAYU: Jurnal Antarabangsa Dunia Melayu, 8 (2): hlm. 257 - 287. 
